\title{
Equity-Based Compensation For Outside Directors And Cost Of Equity Capital
}

Induck Hwang, Korea Advanced Institute of Science and Technology (KAIST), Korea

Hyungtae Kim, Arkansas State University, USA

Sangshin Pae, Arkansas State University, USA

\begin{abstract}
This study provides evidence on the association between equity-based compensation for outside directors and the implied cost of equity capital. Based on the premise that equity-based compensation for outside directors better aligns the interests of the directors with those of shareholders, we investigate whether the more equity-based compensation is granted to outside directors, the lower cost of equity capital firms enjoy. We find a negative relationship between the proportion of equity-based compensation to total compensation for outside directors and the cost of equity capital. Our findings suggest that equity-based compensation for outside directors, by motivating the directors to play their monitoring role more faithfully, reduces agency risks resulting in the lower cost of equity capital.
\end{abstract}

Keywords: Equity-Based Compensation; Cost of Equity Capital; Information Asymmetry; Corporate Governance

\section{INTRODUCTION}

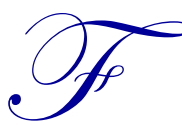

irms inherently suffer from agency problems between shareholders and managers due to the separation of ownership and control (Jensen \& Meckling, 1976). Specifically, the agency problems can be classified into two separate problems. On one hand, managers have incentives to make decisions pursuing their own interests against shareholders' interests, which results in a moral hazard problem. On the other hand, shareholders cannot figure out the true economic value of the firm, which creates an adverse selection problem (Ashbaugh et al., 2009b). Since both the problems expose shareholders to a greater agency risk, equity investors rationally demand a higher premium for firms with higher agency risk and raise the cost of equity capital.

However, firms with effective governance mechanism experience lesser degree of agency problems. Strong corporate governance restricts managers' opportunistic behavior and reduces information asymmetry mitigating agency problems. Thus, it is apparent that corporate governance has an influence on the cost of equity capital via decreasing agency risk. Ample studies have investigated the kinds of governance attributes which affect the cost of equity capital (e.g., Botosan, 1997; Botosan \& Plumlee, 2002; Bhojraj \& Sengupta, 2003; Francis et al., 2004; Attig et al., 2008; Ashbaugh et al., 2009a; Ashbaugh et al., 2009b). Among various governance attributes, we focus on equity-based compensation for outside directors for two reasons. First, outside directors are important constituents of strong corporate governance. The independence of outside directors from managements allows the directors to effectively monitor managers' opportunistic behavior (e.g., Klein, 2002; Ajinkya et al., 2005). Second, equity-based compensation given to outside directors improves the effectiveness of outside directors in monitoring managerial behaviors. Since outside directors are agents of shareholders as well, it is also possible that another type of agency problem between outside directors and shareholders exists. Equity-based compensation to outside directors can play a crucial role as a remedy for such type agency problem. It motivates outside directors to more rigorously monitor the managements of their firm by better aligning the interests of outside directors with those of shareholders. Consequently, improved corporate governance decreases agency risk and cost of equity capital.

In this study, we examine the relationship between the amount of equity-based compensation granted to outside directors and cost of equity capital. Using six specific measures and two composite measures of the cost of equity capital, we find that the proportion of equity-based compensation to total compensation is negatively 
associated with the cost of equity capital. To test the sensitivity of our results to alternative measures of equity-based compensation amount, we use the average amount of equity-based compensation (equity amount), and also separate the amount of stock compensation and that of options. However, the relationship between equity-based compensation and the cost of equity capital is unaffected. Our results suggest that providing equity-based compensation to outside directors can constitute an effective governance mechanism which better aligns the interests between shareholders and outside directors. The results also imply that firms with stronger corporate governance enjoy lower cost of equity capital.

Our findings contribute to the extant studies in two ways. First, we provide a link between the compensation structure of outside directors and the cost of equity capital. We believe this evidence is meaningful because the cost of equity capital is one of the most frequently treated issues in academia, and equity-based compensation is recently attracting much more attention from accounting and finance researchers. Second, this study complements the prior literature that investigates the relationship between corporate governance and cost of equity capital. Rather than exploring the effect of general characteristics of outside directors on cost of equity capital, we extend their work by presenting evidence that a specific compensation scheme for outside directors affects cost of equity capital.

The remainder of the paper is organized as follows. The related research and the hypotheses are discussed in Section 2. In Section 3, I describe the sample and the research design. Section 4 presents the results, and I summarize the findings and conclude this study in Section 5.

\section{RELATED LITERATURE AND PREDICTIONS}

Shareholders delegate their decision rights and oversight roles to a board of directors to prevent the agency problems by managements. Previous studies have shown that board characteristics, such as the composition of a board and board meeting frequency, are related to the effectiveness of the board and thus to strong corporate governance (e.g., Yermack, 1996; Vafeas, 1999; Carcello et al., 2006). Going one step forward, many researchers turned their eyes to the types of directors, especially outside directors. Outside directors are considered to be independent in that they are not employees of the company and unaffiliated with it. The independence of outside directors from management enables them to effectively monitor CEO's opportunistic behavior against shareholders. Empirical literature documents that outside directors help firms build a solid corporate governance system and thereby reduce agency costs by restricting managers' opportunistic behaviors and decreasing information asymmetry. Klein (2002) documents that board independence, proxied by the percentage of outside directors in a board, is negatively associated with the extent to which firms manipulate their earnings. Ajinkya et al. (2005) also find that firms with more outside directors tend to issue more specific, accurate and less optimistically biased management forecast.

However, while outside directors can be the source of strong corporate governance, they can also generate another type of agency problems. For example, outside directors might collude with managers and engage in opportunistic activities pursing their own interests even though the decision ruins the shareholders' wealth (e.g., Brick et al., 2006). As CEOs frequently sits on the nomination committee or exerts influence on the nomination process of outside directors, they might take advantage of the relationship to force outside directors to be on their side (Perry, 2000). Even worse, it is difficult for shareholders to directly monitor and control the behavior of outside directors. The board generally involves in setting its own compensation and deciding upon its own members' continuation of directorship through remuneration committee and nomination committee (Yermack, 2004). In addition, the performance of outside directors is evaluated by other board members and hard to quantify. Therefore, the performance evaluation of outside directors is subject to the discretion of other board members.

In the dearth of a direct mechanism for controlling the behavior of outside directors, equity-based compensation to outside directors can be a fundamental remedy for the agency problem between shareholders and outside directors. By allowing the interests of outside directors to be better aligned with those of shareholders, equity-based compensation incentivizes the directors to more faithfully fulfill their monitoring role on behalf of shareholders. Empirical studies provide evidence on the incentivizing role of equity-based compensation in alleviating agency problems caused by outside directors. Perry (2000) argues that CEOs will be more likely to get fired following bad performance when the outside directors are highly compensated with equity. Ryan and Wiggins 
(2004) suggest a positive association between corporate governance and equity-based compensation for outside directors. That is, firms with strong boards compensate the directors with more equity-based compensation to align their objectives more closely with shareholders'. In addition, Linn and Park (2005) point out firms with more investment opportunities grant larger amounts of equity-based compensation to outside directors. Deutsch (2007) emphasizes that equity-based compensation for outside directors enhances firms' R\&D investment. Fich and Shivdasani (2005) state that equity-based compensation helps align the incentives of outside directors and shareholders, thereby improving firm value. Likewise, Cordeiro et al. (2005) demonstrate that the equity-based compensation for directors is positively associated with future firm performance.

Another stream of research explores the relation between agency risk and the cost of equity capital. For example, Attig et al. (2008) assert a negative association between institutional ownership and cost of equity capital. Ashbaugh et al. (2009b) find firms with more independent directors and more board ownership are exposed to less agency risk, so they have a lower cost of equity capital. Botosan (1997), and Botosan and Plumlee (2002) prove a negative relation between and disclosure quality and cost of equity capital. Francis et al. (2004) document that earnings transparency is negatively associated with cost of equity capital. Similarly, Hail and Leuz (2006) and Ashbaugh et al. (2009a) point out firms with a more extensive regulation environment have a lower cost of equity capital by reducing agency risks. Aggregately, empirical evidence supports the negative association between agency risk and the cost of equity capital.

In conclusion, by tying the interests of outside directors to those of shareholders, equity-based compensation granted to outside directors curtails the possibility of agency problems caused by outside directors as well as managers. The interest alignment allows firms to suffer from lesser degree of agency risk and thereby reduces the firms' cost of equity capital. Based on this reasoning, we hypothesize that the amount of equity-based compensation awarded to outside directors is negatively related to the cost of equity capital.

\section{RESEARCH DESIGN}

\subsection{Sample and Data}

Our sample consists of firms from Compustat, Corporate Library, CRSP, and I/B/E/S databases for the years extending from year 2006 to 2008. Compustat (ЕхесиСотр) provides annual compensation data for each outside director after 2006 as well as other financial data. Directors are classified from Corporate Library as one of the following: inside, gray, or outside. ${ }^{1}$ To fill in the data missing in the Corporate Library database, we handcollect additional director type information from the proxy statements. We obtain the stock price information from the $C R S P$ database. To compute implied cost of equity capital, earnings forecasts are acquired from the $I / B / E / S$ database. We use median analysts' forecasts of $E P S$ at year $\mathrm{t}+1$ and at year $\mathrm{t}+2\left(E P S_{i t+1}\right.$ and $\left.E P S_{i t+2}\right)$, respectively. ${ }^{2}$ We also find analysts' estimation of $E P S$ long-term growth rate (ltg). If $E P S_{i t+2}$ is not available, then we infer $E P S_{i t+2}$ with $E P S_{i t+1}$ and $l t g$. After all variables are taken together, the final sample for the empirical analysis comprises 2,727 firm-year observations from the intersection of the Compustat, Corporate Library, CRSP, and I/B/E/S databases. ${ }^{3}$

\subsection{Measures of Cost of Equity Capital}

In this section, we give a short explanation of the eight measures of implied cost of equity capital that we calculated (COE). Following the extant literature, we use the models to measure implied cost of equity capital based on either the dividend discount model or the residual income model. In detail, we estimate six types of specifications and two types of composite measures to increase the validity and the credibility of the proxies. The first measure of cost of equity capital is $R_{-} P E$, which reflects expected cum-dividend combination earnings for the subsequent two

\footnotetext{
${ }^{1}$ An inside director holds a director position in a firm and is also an employee of the firm at the same time. A gray director holds a director position in a firm and has a special relationship with the CEO. Since a gray director is usually a former employee, current commercial partner or family member of the CEO, he (she) may be easily influenced by the CEO. A director who does not satisfy either of these descriptions is called an independent outside director, and he (she) is independent of the CEO. We only consider independent directors in our analyses. We arrive at similar results when we include gray directors in our analyses.

${ }^{2}$ Mean value of analysts' forecasts shows similar results.

${ }^{3}$ To handle outlier problems, we winsorize continuous variables at the $1 \%$ and $99 \%$ levels.
} 
years. It is the inverse of the forward price-earnings ratio. We consider $R_{-} P E$ as a basic benchmark of implied cost of equity capital.

The next three measures are based on the dividend discount model (e.g., Ohlson \& Juettner-Nauroth, 2005; Easton, 2004; Easton \& Monahan, 2005). These measures use exactly the same model but differ in assumptions on dividend and earnings growth patterns.

$$
P_{i t}=\frac{E P S_{i t+1}}{r}+\frac{E P S_{i t+2}+r \times D P S_{i t+1}-(1+r) \times E P S_{i t+1}}{r \times(r-\text { growth })}
$$

In this equation, $P_{i t}$ is stock price at the year-end, $E P S_{i t+\tau}\left(D P S_{i t+\tau}\right)$ is a forecasted $E P S(D P S)$ of year $\mathrm{t}+\tau$ at year $\mathrm{t}$ and growth is the expected growth rate of earnings. From this equation, we derive (1) $R \_P E G$ under the no dividend and zero growth rate assumptions $\left(D P S_{i t+1}=0\right.$, growth $\left.=0\right),(2) R \_M P E G$ under the zero growth rate assumption (growth $=0$ ), and (3) $R_{-} O J N$ by setting the growth rate to analysts' long-term growth rate (growth $=l t g$ ).

The other two measures are based on the residual income valuation model. These two values are from the same valuation model but are different in assuming the terminal horizon and future growth rates. In evaluating cost of equity capital, $R_{-} C T$, we assume that earnings will expand at a rate of analysts' consensus (ltg) until year t +5 and be constant thereafter. ${ }^{4} R_{-} G L S$ is from Gebhardt et al. (2001). In this model, $R O E$ is presumed to decline at a certain rate from year $\mathrm{t}+3$ to year $\mathrm{t}+12$ and then will be uniform forever. ${ }^{5}$

Table 1: Cost of Equity Capital Calculation

\begin{tabular}{|c|c|c|}
\hline Variables & Valuation Models & Descriptions \\
\hline$R \_P E$ & $P_{i t}=\frac{E P S_{i t+1}+R_{-} P E \times D P S_{i t}+E P S_{i t+2}}{\left(1+R_{-} P E\right)^{2}-1}$ & \\
\hline$R \_P E G$ & $P_{i t}=\frac{E P S_{i t+2}-E P S_{i t+1}}{R_{-} P E G^{2}}$ & \\
\hline$R \_M P E G$ & $P_{i t}=\frac{E P S_{i t+2}+R_{-} M P E G \times D P S_{i t+1}-E P S_{i t+1}}{R_{-} M P E G^{2}}$ & \\
\hline$R \_O J N$ & $P_{i t}=\frac{E P S_{i t+1}}{R_{-} O J N}+\frac{E P S_{i t+2}+R_{-} O J N \times D P S_{i t+1}-\left(1+R_{-} O J N\right) \times E P S_{i t+1}}{R_{-} O J N \times\left(R_{-} O J N-l \text { ltg }\right)}$ & \\
\hline$R \_C T$ & $P_{i t}=B P S_{i t}+\sum_{\tau=1}^{4} \frac{\left(R O E_{i t+\tau}-R_{-} C T\right) \times B P S_{i t+\tau-1}}{\left(1+R_{-} C T\right)^{\tau}}+\frac{\left(R O E_{i t+5}-R_{-} C T\right) \times B P S_{i t+4}}{R_{-} C T \times\left(1+R_{-} C T\right)^{4}}$ & $\begin{array}{l}R O E_{i t+\tau}=E P S_{i t+\tau} / B P S_{i t+\tau-1}, E P S_{i t+\tau}= \\
E P S_{i t+2} *(1+l t g)^{\tau-2} \text { for } \tau>2 . B P S_{i t+\tau}=B P S_{i t+\tau-1} \\
+E P S_{i t+\tau} *(1-K) . K=\max \left(0, \min \left(D P S_{i t} / E P S_{i t} \text {, }\right.\right. \\
\text { 1)) for profitable firms. } K=\max (0, \\
\left.\min \left(D P S_{i t} /\left(0.06^{*} B P S_{i t}\right), 1\right)\right) \text { for loss firms. }\end{array}$ \\
\hline$R \_G L S$ & $P_{i t}=B P S_{i t}+\sum_{\tau=1}^{11} \frac{\left(R O E_{i t+\tau}-R_{-} G L S\right) \times B P S_{i t+\tau-1}}{\left(1+R_{-} G L S\right)^{\tau}}+\frac{\left(R O E_{i t+12}-R_{-} G L S\right) \times B P S_{i t+11}}{R_{-} G L S \times\left(1+R_{-} G L S\right)^{11}}$ & $\begin{array}{l}R O E_{i t+\tau}=E P S_{i t+\tau} / B P S_{i t+\tau-l} \text { for } \tau=1,2 . \\
\operatorname{ROE}_{i t+\tau}=R O E_{i t+\tau-1}-\text { fade for } \tau>2 . \text { fade }= \\
\left(R O E_{i t+\tau-2}-H I R O E_{t}\right) / 10, H I R O E_{t} \text { is the } \\
\text { industry median } R O E \text { from year } t-4 \text { to year } t . \\
B P S_{i t+\tau}=B P S_{i t+\tau-1} *\left(1+R O E_{i t+\tau} *(1-K)\right) . K= \\
\max \left(0, \min \left(D P S_{i t} / E P S_{i t}, 1\right)\right) \text { for profitable } \\
\text { firms. } K=\max \left(0, \min \left(D P S_{i t} /\left(0.06^{*} B P S_{i t}\right), 1\right)\right) \\
\text { for loss firms. }\end{array}$ \\
\hline
\end{tabular}

The last two measures are $R \_A V G 1$ and $R \_A V G 2$. Because all six measures might have errors in gauging cost of equity capital, we aggregate these together to reduce possible measurement error caused from each model. $R \_A V G 1$ is the average value of six measures; $\left(R_{-} P E+R_{-} P E G+R_{-} M P E G+R_{-} O J N+R \_C T+R_{-} G L S\right) / 6$.

\footnotetext{
${ }^{4}$ Following Claus and Thomas (2001), we also presume that the earnings will grow at an inflation rate (US 10-year bond yield -3 percent) or at a rate of analysts' consensus (ltg). We find similar results.

${ }^{5}$ In Gebhardt et al. (2001), they assume $R O E$ will diminish at the same rate toward the industry median $R O E$ from year $\mathrm{t}+3$ to year $\mathrm{t}+12$.
} 
$R_{-} A V G 2$ is the average value of four measures excluding maximum and minimum value from the six measures; $\left(R_{-} P E+R \_P E G+R \_M P E G+R \_O J N+R \_C T+R \_G L S-\max \left[R \_P E, R \_P E G, R \_M P E G, R \_O J N, R \_C T, R \_G L S\right]\right.$ $\left.-\min \left[R \_P E, R \_P E G, R \_M P E G, R \_O J N, R \_C T, R \_G L S\right]\right) / 4$.

\subsection{Empirical Model}

We use the following $O L S$ regression model (with the detailed subscripts omitted).

COE $=\beta_{0}+\beta_{1}$ DIR_COMP $+\beta_{2}$ CEO_COMP $+\beta_{3}$ CEOICHAIR $+\beta_{4}$ OUTSIDE $+\beta_{5}$ PROBLEM $+\beta_{6} B O A R D S I Z E+$ $\beta_{7} T O P O W N+\beta_{8} S T D R E T+\beta_{9} D I S P E R S+\beta_{10} B E T A+\beta_{11} M O M+\beta_{12} S I Z E+\beta_{13} M B+\varepsilon$

The independent variable DIR_COMP indicates equity-based compensation paid to the outside directors. It is the ratio of total equity-based compensation for all outside directors over total compensation (cash and equity, etc.) for all outside directors (i.e., total equity-based compensation divided by total compensation). Since equity compensation for outside directors will tie the interests of directors and shareholders together, a higher proportion of equity compensation for outside directors will result in a lower level of cost of equity capital. So, we expect $\beta_{1}$ to be negative. CEO_COMP represents equity-based compensation for the CEO, which is similarly defined as $D I R \_C O M P$. According to the prior literature, managers' behavior varies. Sometimes, managers will care more about the shareholders due to an alignment of interests (e.g., Nagar et al., 2003), but sometimes, managers will be less care about the shareholders. Rather they only focus on creating their own benefits, for example, right before the stock option grants date (e.g., Aboody \& Kasznik, 2000). Thus, we do not make any expectations on $\beta_{2}$. Following previous studies, we include the other control and firm characteristic variables (e.g., Hail \& Leuz, 2006; Attig et al., 2008; Ashbaugh et al., 2009a; Ashbaugh et al., 2009b).

CEOICHAIR, OUTSIDE, PROBLEM, BOARDSIZE, and TOPOWN are corporate governance related variables. CEO/CHAIR implies CEO and chairman duality. It is 1 if a CEO is also a chairman of the board and 0 otherwise. The dual position of CEO and Chairman usually weakens corporate governance since board members' monitoring activities will be restricted by the CEO. We expect $\beta_{3}$ to be positive. OUTSIDE is the proportion of outside directors on the board. More outside directors intensify the corporate governance, and we anticipate negative coefficients on $\beta_{4}$ (e.g., Ashbaugh et al., 2009a; Ashbaugh et al., 2009b). PROBLEM indicates whether there is a director who failed to meet the attendance standards. ${ }^{6}$ It equals 1 if there is at least one director who violates the standards and 0 otherwise. An attendance problem can be interpreted as weak governance. Therefore, we expect a positive value of $\beta_{5}$. BOARDSIZE is the number of directors in the board. It is controversial since a larger board is sometimes efficient but sometimes not. In some cases, a larger board is more efficient since there are more directors to oversee managers with more knowledge and a better background, but in other cases, it is inefficient since there are coordination problem among the directors (e.g., Yermack, 1996). Therefore, we do not predict any directions on $\beta_{6}$. TOPOWN is the percentage of total shares held by the top five executives to total outstanding shares. Managers who possess larger shares are inclined to defend the shareholders' interests. Warfield et al. (1995) report that as management ownership gets larger, earnings will be more informative and discretionary accruals will be smaller. The results clarify that management pursues value-maximizing actions. So, we predict negative coefficients on $\beta_{7}$.

Furthermore, we include other variables. STDRET is standard deviation of daily stock returns for the past 24 months (e.g., Hail \& Leuz, 2006; Attig et al., 2008), DISPERS is the standard deviation of all forecasts made by analysts divided by median analysts' forecasts (e.g., Attig et al., 2008; Hope et al., 2008), BETA measures systematic risk suggested by the Capital Market Asset Pricing Model (e.g., Hail \& Leuz, 2006; Ashbaugh et al., 2009a; Chen et al., 2009). MOM captures stock price momentum (e.g., Hope et al., 2008; Chen et al., 2009), which is defined the stock return during the previous 12 months. SIZE is the log of market value of equity at the beginning of the year, and $M B$ is the market-to-book value of the equity ratio (e.g., Hail \& Leuz, 2006; Attig et al., 2008; Ashbaugh et al., 2009a).

Shareholders will require less risk premium when the firm is less risky. That is, when the market is less volatile (STDRET, DISPERS). We expect positive coefficients on $\beta_{8}$ and $\beta_{9}$. A higher BETA implies a higher systematic risk. Therefore, we anticipate positive coefficients on $\beta_{10}$ since investors require higher cost of equity

${ }^{6}$ The required attendance rate is $75 \%$ or more. 
capital for higher BETA firms based on Capital Market Asset Pricing Model. According to Guay et al. (2005), previous stock returns might be higher (lower) due to the delayed recognition of bad (good) news. In this case, the value of implied cost of equity capital tends to have downward (upward) bias. So, prior literature reports negative coefficients on stock return momentum $(M O M)$. We also expect $\beta_{11}$ to be negative. Finally, we control SIZE and $M B$. We anticipate negative $\beta_{12}$ since SIZE is negatively associated with cost of equity as a proxy for liquidity. In other words, investors require lower risk premium for more liquid stocks. The $M B$ ratio, sometimes infers a distress factor, which is inclined to have a lower value (i.e., lower $M B$ ratio) for a financially distressed firm. Investors require higher risk premium, i.e. cost of equity capital (e.g., Hail \& Leuz, 2006; Attig et al., 2008; Hope et al., 2008) for distressed firms. Thus, we predict positive coefficients on $\beta_{13}$.

\section{RESULTS}

\subsection{Descriptive Statistics}

In Table 2 and Table 3, we introduce the descriptive statistics on key variables. Our sample has 2,727 firmyear level observations ranging from year 2006 to 2008. In Table 2, we report the distribution of implied cost of equity capital based on eight different methods. Mean (median) values vary between $0.0663(0.0637)$ and 0.1139 (0.1044). $R \_O J N$ is the highest and $R \_P E$ is the lowest mean (median) value.

Table 2: Descriptive Statistics on Cost of Equity Capital

\begin{tabular}{lcccccccc}
\hline & \# of obs. & Mean & Median & Stdev. & $\mathbf{1 \%}$ & $\mathbf{2 5 \%}$ & $\mathbf{7 5 \%}$ & $\mathbf{9 9 \%}$ \\
\hline$R \_P E$ & 2,727 & 0.0663 & 0.0637 & 0.0285 & 0.0079 & 0.0253 & 0.0637 & 0.1179 \\
$R \_P E G$ & 2,727 & 0.1048 & 0.0937 & 0.0503 & 0.0252 & 0.0451 & 0.0937 & 0.2027 \\
$R \_M P E G$ & 2,727 & 0.1123 & 0.0996 & 0.0521 & 0.0324 & 0.0521 & 0.0996 & 0.2113 \\
$R \_O J N$ & 2,727 & 0.1139 & 0.1044 & 0.0995 & 0.0000 & 0.0010 & 0.1044 & 0.2884 \\
$R \_C T$ & 2,727 & 0.0845 & 0.0798 & 0.0299 & 0.0312 & 0.0465 & 0.0798 & 0.1374 \\
$R \_G L S$ & 2,727 & 0.1073 & 0.0977 & 0.0571 & 0.0165 & 0.0392 & 0.0977 & 0.2075 \\
$R \_A V G 1$ & 2,727 & 0.0987 & 0.0910 & 0.0378 & 0.0404 & 0.0533 & 0.0910 & 0.1756 \\
$R \_A V G 2$ & 2,727 & 0.0970 & 0.0898 & 0.0362 & 0.0391 & 0.0544 & 0.0898 & 0.1698 \\
\hline
\end{tabular}

Table 3: Descriptive Statistics on Independent and Control Variables

\begin{tabular}{|c|c|c|c|c|c|c|}
\hline & \# of obs. & Mean & Median & Stdev. & $25 \%$ & $75 \%$ \\
\hline \multicolumn{7}{|l|}{ Independent Variables } \\
\hline$\overline{D I R \_C O M P}$ & 2,727 & 0.5257 & 0.5357 & 0.2132 & 0.4183 & 0.6686 \\
\hline$D I R \_R A M T(\$ 1,000)$ & 2,727 & 94 & 75 & 94 & 39 & 122 \\
\hline \multicolumn{7}{|l|}{ Control Variables } \\
\hline$\overline{C E O \_C O M P}$ & 2,727 & 0.6463 & 0.7301 & 0.2528 & 0.5419 & 0.8262 \\
\hline$C E O \_R A M T(\$ 1,000)$ & 2,727 & 4,105 & 2,404 & 5,762 & 901 & 5,226 \\
\hline CEO/CHAIR & 2,727 & 0.6464 & 1.0000 & 0.4781 & 0.0000 & 1.0000 \\
\hline OUTSIDE & 2,727 & 0.7620 & 0.7777 & 0.1232 & 0.6923 & 0.8666 \\
\hline PROBLEM & 2,727 & 0.0722 & 0 & 0.2589 & 0 & 0 \\
\hline BOARDSIZE & 2,727 & 9.1840 & 9 & 2.1399 & 8 & 11 \\
\hline TOPOWN (\%) & 2,727 & 2.9203 & 0.6804 & 6.9597 & 0.2390 & 2.0045 \\
\hline INST_OWN (\%) & 2,727 & 79.1956 & 81.9033 & 18.1474 & 70.3199 & 92.6779 \\
\hline STDRET & 2,727 & 0.0894 & 0.0833 & 0.0375 & 0.0611 & 0.1115 \\
\hline DISPERS & 2,727 & 0.1146 & 0.0612 & 0.1742 & 0.0329 & 0.1207 \\
\hline BETA & 2,727 & 1.1656 & 1.0670 & 0.6579 & 0.6958 & 1.5111 \\
\hline$M O M$ & 2,727 & 0.0225 & 0.0044 & 0.3724 & -0.2221 & 0.2174 \\
\hline$S I Z E$ & 2,727 & 21.5836 & 21.4264 & 1.5042 & 20.4699 & 22.5504 \\
\hline$M B$ & 2,727 & 3.0126 & 2.3058 & 2.6253 & 1.5652 & 3.5595 \\
\hline
\end{tabular}

$\overline{D I R \_C O M P}=$ ratio of total equity-based compensation for outside directors over total compensation for outside directors in a firm during the fiscal year (i.e. total equity-based incentives / total incentives); DIR_RAMT = average amount of equity-based incentives to each director in a firm during the fiscal year; $C E O C C O M P$ = ratio of total equity-based compensation for CEO over total compensation for CEO; $C E O \_R A M T=$ total amount of equity-based incentives for CEO in a firm during the fiscal year; CEO/CHAIR = 1 if the CEO also holds chairman of the board, and 0 otherwise; OUTSIDE = total number of independent outside directors over total number of directors; PROBLEM $=1$ if there is a director attendance problem (for each director, attendance rate should be above $75 \%$ ), and 0 otherwise; BOARDSIZE = total number of directors in a board; TOPOWN $=$ the percentage of total shares held by top five executives to total outstanding shares; STDRET = standard deviation of daily stock returns for the previous 24 months; DISPERS = the standard deviation of all forecasts made by analysts divided by median analysts' forecasts; BETA = estimates from Capital Market Asset Pricing Model; $M O M=$ stock return during the previous 12 months; $S I Z E=\log$ of market value of equity at the beginning of year; $M B=$ market-to-book value of equity ratio. 
Table 3 shows descriptive statistics of independent and control variables. On average, outside directors in a firm receive approximately 53\% of their total compensation in stock and/or options. In dollar terms, each outside director is granted $\$ 94,000$ of equity-based compensation on average. On the other hand, CEOs are rewarded with much more stock and/or options than outside directors. They receive $65 \%$ of total their compensation, approximately $\$ 4.1$ million in US dollars, as equity-based compensation. The mean value of CEO/CHAIR (0.6464) implies that CEOs of $65 \%$ of firm-year observations hold a chairman position at the same time in the sample. Among the board of directors, $76 \%$ are outside members. There are only a few attendance problems in our sample (mean of PROBLEM: 0.0722). There are approximately 9 members on average. The top five managers hold $2.92 \%$ of shares of the firm.

\subsection{Results for Difference in Mean (Median) Tests}

Table 4 provides the results for difference in mean (median) tests. We divide the sample into two different groups based on the median of DIR_COMP. High (Low) DIR_COMP consists of above (below)-median DIR_COMP observations. We examine whether there is a difference between these two groups. We only report the variables related to the cost of equity capital, CEO compensation $\left(C E O \_C O M P\right)$ and corporate governance (CEO/CHAIR, OUTSIDE, PROBLEM, BOARDSIZE and TOPOWN).

The results explain that there is a significant difference in the cost of equity capital between the groups. Among the eight different specifications, six confirm that higher equity compensation groups have a lower level of the cost of equity capital (except $R_{-} O J N$ and $R_{-} G L S$ ), which is generally consistent with our prediction. Moreover, these also infer that there are significant differences in CEO_COMP, BOARDSIZE, and TOPOWN. We find that higher proportion groups grant more equity compensation to CEOs (CEO_COMP) as Brick et al. (2006) explained. These groups also have a small board size (BOARDSIZE) and possess lower top management ownership (TOPOWN) as prior literature described. ${ }^{7}$

Table 4: Difference in Mean (Median) Tests

\begin{tabular}{|c|c|c|c|c|c|c|}
\hline & \multicolumn{2}{|c|}{$\begin{array}{c}\text { High DIR_COMP } \\
(N=1,364)\end{array}$} & \multicolumn{2}{|c|}{$\begin{array}{c}\text { Low DIR_COMP } \\
(N=1,363)\end{array}$} & \multicolumn{2}{|c|}{ High - Low } \\
\hline & Mean & Median & Mean & Median & Mean & Median \\
\hline$R \_P E$ & 0.0596 & 0.0576 & 0.0642 & 0.0608 & $-0.0047 * * *$ & $-0.0032 * * *$ \\
\hline$R \_P E G$ & 0.1006 & 0.0927 & 0.1050 & 0.0945 & $-0.0044 * * *$ & $-0.0018 * * *$ \\
\hline$R \_M P E G$ & 0.1008 & 0.0928 & 0.1052 & 0.0945 & $-0.0044 * * *$ & $-0.0017 * * *$ \\
\hline$R \_O J N$ & 0.1148 & 0.1065 & 0.1124 & 0.1047 & $0.0020 * * *$ & $0.0017 * * *$ \\
\hline$R \_C T$ & 0.0757 & 0.0734 & 0.0791 & 0.0761 & $-0.0033 * * *$ & $-0.0027 * * *$ \\
\hline$R \_G L S$ & 0.1099 & 0.0934 & 0.1125 & 0.0950 & $-0.0026 * * *$ & $-0.0016 * * *$ \\
\hline$R \_A V G 1$ & 0.0938 & 0.0875 & 0.0967 & 0.0897 & $-0.0029 * * *$ & $-0.0023 * * *$ \\
\hline$R \_A V G 2$ & 0.0904 & 0.0831 & 0.0940 & 0.0872 & $-0.0036^{* * *}$ & $-0.0041 * * *$ \\
\hline$\overline{C E O}$ _COMP & 0.6860 & 0.7684 & 0.6342 & 0.7135 & $0.0520 * * *$ & $0.0549 * * *$ \\
\hline CEO/CHAIR & 0.5669 & 1.0000 & 0.5544 & 1.0000 & $0.0130 * * *$ & $0.0000 * * *$ \\
\hline OUTSIDE & 0.7447 & 0.7500 & 0.7356 & 0.7500 & $0.0090 * * *$ & $0.0000 * * *$ \\
\hline PROBLEM & 0.0898 & 0.0000 & 0.0827 & 0.0000 & $0.0007 * * *$ & $0.0000 * * *$ \\
\hline BOARDSIZE & 9.1258 & 9.0000 & 9.6523 & 9.0000 & $-0.5265 * * *$ & $0.0000 * * *$ \\
\hline TOPOWN & 2.3757 & 0.6931 & 3.2022 & 0.7693 & $-0.8265 * * *$ & $-0.0761 * * *$ \\
\hline
\end{tabular}

$\overline{C E O \_C O M P}=$ ratio of total equity-based compensation for CEO over total compensation for CEO; CEO/CHAIR = 1 if the CEO also holds chairman of the board, and 0 otherwise; OUTSIDE = total number of independent outside directors over total number of directors; PROBLEM = 1 if there is a director attendance problem (for each director, attendance rate should be above $75 \%$ ), and 0 otherwise; BOARDSIZE $=$ total number of directors in a board; TOPOWN $=$ the percentage of total shares held by top five executives to total outstanding shares; $t$-statistics are in parentheses. ***, **, and * denote significance of parameter estimates at the $0.01,0.05$, and 0.10 levels, respectively.

\footnotetext{
${ }^{7}$ Many studies (e.g., Dechow et al., 1996; Yermack, 1996; Nagar et al., 2003; Ajinkya et al., 2005; Karamanou and Vafeas, 2005; Adams and Ferreira, 2008) suggest that characteristics of strong corporate governance are negatively associated with board size and management ownership.
} 


\subsection{Results for Multivariate Tests}

Table 5 contains the impact of the proportion of equity-based compensation for outside directors on cost of equity capital. The results are based on the $O L S$ regressions. We're especially interested in DIR_COMP. ${ }^{8}$

From column 1 to column 6, the results show that the estimated coefficients of DIR_COMP are negative and statistically significant. These results support our conjecture that firms with higher equity-based compensation for outside directors have a lower cost of equity capital. Among the six coefficients of CEO_COMP, three coefficients are positive and statistically significant and we think these results might suggest that shareholders recognize CEOs' opportunistic behavior (e.g., Aboody \& Kasznik, 2000), so shareholders require a higher cost of equity capital. OUTSIDE have positive coefficients differing from our prediction. BOARDSIZE confirms the idea that a small board is more efficient in monitoring (e.g., Yermack, 1996). TOPOWN has negative coefficients and this is evidence of interest alignment between managers and shareholders.

Higher values of STDRET and/or DISPERS suggest that the market is highly volatile. Shareholders naturally require a higher risk premium for highly volatile firms. Positive coefficients on STDRET and DISPERS clarify this explanation. The coefficients of SIZE alternate, but most of them support our expectation. SIZE has negative coefficients, which show that larger firms are more liquid in trading. $M B$ consistently has negative coefficients as firms with lower $M B$ ratio are highly distressed.

Furthermore, when we use two composite measures to improve soundness of the proxies, we find consistent results. The estimated coefficients of DIR_COMP are negative and significant. In addition to that, coefficients of the other variables replicate previous results. Coefficients of CEO_COMP and BOARDSIZE are positive and significant. TOPOWN has a negative coefficient, and the other variables present similar results (results unreported).

\section{SENSITIVITY ANALYSES}

\subsection{Alternative Measure of Equity-Based Compensation}

For the sensitivity tests, we apply an additional measure of equity-based compensation for outside directors. Alternatively, we define equity-based compensation for outside directors as the dollar amount of the equity-based compensation awarded to outside directors (DIR_AMT). DIR_AMT is calculated as the average equity-based compensation for each outside director. The regression results generally reveal that DIR_AMT and the implied cost of equity capital have a negative and statistically significant association (results unreported). Even if the coefficients are not all significant, at least the directions are consistent with our expectations (In $R_{-} P E$ model and $R_{-} C T$ model, the coefficients are negatively significant at the 0.01 level). The overall results suggest that larger amounts of equitybased compensation for outside directors strengthen the monitoring role of outside directors and reduce agency risk.

\subsection{Separate Effects of Stock and Option Awards for Directors on the Cost of Equity Capital}

Different types of equity-based compensation may affect the implied cost of equity capital in different ways. Problematically, one particular type of equity-based compensation may be driving the results. In addition, outside directors may be sensitive to whether their equity-based compensation is in the form of stock or options. Hence, we conduct further analysis separating the two types of equity-based compensation. The results shown in Table 7 reveal that option-based compensation for outside directors significantly lowers the cost of equity capital. The reason is that only options exhibit a statistically significant effect, which is consistent with Bryan et al. (2000), who suggest that stock options are more efficient than stock grants in motivating outside directors because the payoffs from stock options are convex. In sum, the results suggest that option-based compensation for outside directors reduces the cost of equity capital.

\footnotetext{
${ }^{8}$ For the sensitivity tests, we alternatively adopt various specifications of DIR_COMP. We use the average amount of equity compensation for outside directors, and we also separate stock and options and measure the proportion of stock and options, respectively. The results are statistically similar and will be shown later.
} 


\begin{tabular}{|c|c|c|c|c|c|c|c|c|c|c|c|c|}
\hline \multirow[b]{2}{*}{ Intercept } & \multicolumn{2}{|c|}{$\begin{array}{c}\text { (Column 1) } \\
\text { R_PE }\end{array}$} & \multicolumn{2}{|c|}{$\begin{array}{c}\text { (Column 2) } \\
\text { R_PEG }\end{array}$} & \multicolumn{2}{|c|}{$\begin{array}{c}\text { (Column 3) } \\
R \_M P E G\end{array}$} & \multicolumn{2}{|c|}{$\begin{array}{c}\text { (Column 4) } \\
\text { R_OJN }\end{array}$} & \multicolumn{2}{|c|}{$\begin{array}{c}\text { (Column 5) } \\
\text { R_CT }\end{array}$} & \multicolumn{2}{|c|}{$\begin{array}{c}\text { Column 6) } \\
\text { R_GLS }\end{array}$} \\
\hline & 0.0289 & $(2.72) * * *$ & 0.0661 & $(3.74) * * *$ & 0.0679 & $(3.83)^{* * *}$ & 0.0559 & $(1.62)$ & 0.0225 & $(2.23)^{* *}$ & 0.0077 & $(0.23)$ \\
\hline DIR_COMP & -0.0080 & $(-3.00) * * *$ & -0.0093 & $(-2.07)^{* *}$ & -0.0090 & $(-2.01) * *$ & 0.0062 & $(0.71)$ & -0.0073 & $(-2.87) * * *$ & -0.0099 & $(-1.20)$ \\
\hline CEO_COMP & 0.0082 & $(3.52)^{* * *}$ & 0.0043 & $(1.10)$ & 0.0041 & $(1.04)$ & -0.0006 & $(-0.08)$ & 0.0072 & $(3.26)^{* * *}$ & 0.0139 & $(1.93)^{*}$ \\
\hline CEO/CHAIR & -0.0005 & $(-0.42)$ & -0.0007 & $(-0.40)$ & -0.0007 & $(-0.39)$ & -0.0047 & $(1.32)$ & 0.0004 & $(0.38)$ & 0.0002 & $(0.06)$ \\
\hline OUTSIDE & 0.0083 & $(1.98)^{* *}$ & 0.0214 & $(3.04) * * *$ & 0.0214 & $(3.04)^{* * *}$ & 0.0445 & $(3.25)^{* * *}$ & 0.0101 & $(2.53)^{* *}$ & 0.0196 & $(1.51)$ \\
\hline PROBLEM & -0.0015 & $(-0.81)$ & -0.0037 & $(-1.18)$ & -0.0037 & $(-1.17)$ & -0.0079 & $(-1.28)$ & -0.0013 & $(-0.72)$ & 0.0072 & $(1.23)$ \\
\hline BOARDSIZE & 0.0009 & $(3.36)^{* * * *}$ & 0.0015 & $(.22) * * *$ & 0.0015 & $(3.22) * * *$ & 0.0016 & $(1.74)^{*}$ & 0.0009 & $(3.58) * * *$ & 0.0027 & $(3.12)^{* * *}$ \\
\hline TOPOWN & -0.0001 & $(-1.44)$ & -0.0001 & $(0.41)$ & -0.0001 & $(-0.41)$ & 0.0005 & (1.57) & -0.0002 & $(-1.83)^{*}$ & -0.0010 & $(-3.23)^{* * *}$ \\
\hline STDRET & 0.0039 & $(0.20)$ & 0.2687 & $(8.21)^{* * *}$ & 0.2665 & $(8.12)^{* * *}$ & 0.4767 & $(7.44)^{* * *}$ & 0.0806 & $(4.32) * * *$ & 0.4239 & $(6.98) * * *$ \\
\hline DISPERS & -0.0006 & $(-1.11)$ & 0.0039 & $(4.29) * * *$ & 0.0039 & $(4.28) * * *$ & 0.0069 & $(3.86)^{* * *}$ & 0.0002 & $(0.32)$ & 0.0042 & $(2.45)^{* *}$ \\
\hline BETA & 0.0058 & $(5.04) * * *$ & 0.0217 & $(11.35)^{* * *}$ & 0.0217 & $(11.33)^{* * *}$ & 0.0264 & $(7.07)^{* * *}$ & 0.0104 & $(9.53)^{* * *}$ & 0.0198 & $(5.60) * * *$ \\
\hline MOM & -0.0217 & $(-14.65)^{* * *}$ & -0.0478 & $(-19.28)^{* * *}$ & -0.0479 & $(-19.27) * * *$ & -0.0444 & $(-9.15) * * *$ & -0.0262 & $(-18.51)^{* * *}$ & -0.0137 & $(-2.98) * * *$ \\
\hline SIZE & 0.0006 & $(1.26)$ & -0.0015 & $(-1.80)^{*}$ & -0.0016 & $(-1.89)^{*}$ & -0.0026 & $(-1.65)^{*}$ & 0.0010 & $(2.19)^{* *}$ & 0.0000 & $(0.01)$ \\
\hline$M B$ & -0.0004 & $(-3.14) * * *$ & -0.0007 & $(-3.48) * * *$ & -0.0007 & $(-3.48) * * *$ & -0.0003 & $(-0.64)$ & -0.0003 & $(-2.56) * *$ & 0.0014 & $(3.90) * * *$ \\
\hline \# of obs. & \multicolumn{2}{|c|}{2,727} & \multicolumn{2}{|c|}{2,727} & \multicolumn{2}{|c|}{2,727} & \multicolumn{2}{|c|}{2,727} & \multicolumn{2}{|c|}{2,727} & \multicolumn{2}{|c|}{2,727} \\
\hline Adjusted $R^{2}$ & \multicolumn{2}{|c|}{0.1247} & \multicolumn{2}{|c|}{0.2380} & \multicolumn{2}{|c|}{0.2373} & \multicolumn{2}{|c|}{0.1167} & \multicolumn{2}{|c|}{0.1027} & \multicolumn{2}{|c|}{0.0664} \\
\hline
\end{tabular}

DIR COMP = ratio of total equity-based compensation for outside directors over total compensation for outside directors in a firm during the fiscal year (i.e. total equity-based incentives / total incentives); $C E O \_C O M P=$ ratio of total equity-based compensation for CEO over total compensation for CEO; CEO/CHAIR = 1 if the CEO also holds chairman of the board, and 0 otherwise; $O U T S I D E=$ total number of independent outside directors over total number of directors; PROBLEM $=1$ if there is a director attendance problem (for each director, attendance rate should be above $75 \%$ ), and 0 otherwise; BOARDSIZE = total number of directors in a board; TOPOWN = the percentage of total shares held by top five executives to total outstanding shares; STDRET = standard deviation of daily stock returns for the previous 24 months; DISPERS = the standard deviation of all forecasts made by analysts divided by median analysts' forecasts; BETA = estimates from Capital Market Asset Pricing Model; $M O M=$ stock return during the previous 12 months; SIZE = log of market value of equity at the beginning of year; $M B=$ market-to-book value of equity ratio; (Asymptotic) $t$-statistics are in parentheses. $* * * * *$, and $*$ denote significance of parameter estimates at the $0.01,0.05$, and 0.10 levels, respectively. 


\begin{tabular}{|c|c|c|c|c|c|c|c|c|c|c|c|c|}
\hline \multirow[b]{2}{*}{ Intercept } & \multicolumn{2}{|c|}{$\begin{array}{c}\text { Column 1) } \\
\quad R \_P E\end{array}$} & \multicolumn{2}{|c|}{$\begin{array}{c}\text { (Column 2) } \\
\quad R \_P E G\end{array}$} & \multicolumn{2}{|c|}{$\begin{array}{c}\text { (Column 3) } \\
\text { R_MPEG }\end{array}$} & \multicolumn{2}{|c|}{$\begin{array}{c}\text { (Column 4) } \\
\text { R_OJN }\end{array}$} & \multicolumn{2}{|c|}{$\begin{array}{c}\text { (Column 5) } \\
\text { R_CT }\end{array}$} & \multicolumn{2}{|c|}{$\begin{array}{c}\text { (Column 6) } \\
\quad R_{-} G L S\end{array}$} \\
\hline & 0.0319 & $(3.02) * * *$ & 0.0696 & $(3.94)^{* * *}$ & 0.0715 & $(4.04)^{* * *}$ & 0.0574 & $(1.66)^{*}$ & 0.0254 & $(2.53) * *$ & 0.0164 & $(0.50)$ \\
\hline STOCK & -0.0004 & $(0.13)$ & -0.0004 & $(-0.08)$ & 0.0000 & $(0.01)$ & 0.0098 & $(1.00)$ & 0.0000 & $(0.01)$ & 0.0118 & $(1.27)$ \\
\hline OPTION & -0.0134 & $(-4.75)^{* * *}$ & -0.0155 & $(-3.26)^{* * *}$ & -0.0153 & $(-3.22)^{* * *}$ & 0.0039 & $(0.42)$ & -0.0126 & $(-4.66) * * *$ & -0.0257 & $(-2.93) * *$ \\
\hline CEO_COMP & 0.0079 & $(3.39)^{* * *}$ & 0.0039 & $(1.00)$ & 0.0037 & $(0.94)$ & -0.0008 & $(-0.10)$ & 0.0069 & $(3.12)^{* * *}$ & 0.0129 & $(1.80)^{*}$ \\
\hline CEO/CHAIR & -0.0007 & $(-0.65)$ & -0.0010 & $(-0.57)$ & -0.0010 & $(-0.55)$ & -0.0048 & $(-1.35)$ & 0.0002 & $(0.15)$ & -0.0005 & $(-0.16)$ \\
\hline OUTSIDE & 0.0052 & $(1.23)$ & 0.0177 & $(2.51)^{* *}$ & 0.0176 & $(2.49) * *$ & 0.0431 & $(3.11)^{* * *}$ & 0.0071 & $(1.76)^{*}$ & 0.0106 & $(0.81)$ \\
\hline PROBLEM & -0.0015 & $(-0.82)$ & -0.0037 & $(-1.19)$ & -0.0037 & $(-1.18)$ & -0.0079 & $(-1.28)$ & -0.0013 & $(-0.74)$ & 0.0071 & $(1.23)$ \\
\hline BOARDSIZE & 0.0007 & $(2.46)^{* *}$ & 0.0012 & $(2.58) * *$ & 0.0012 & $(2.57)^{* *}$ & 0.0015 & $(1.60)$ & 0.0007 & $(2.66)^{* * *}$ & 0.0020 & $(2.28)^{* *}$ \\
\hline TOPOWN & -0.0001 & $(-1.41)$ & -0.0001 & $(-0.39)$ & -0.0001 & $(-0.39)$ & 0.0005 & $(1.58)$ & -0.0002 & $(-1.81)^{*}$ & -0.0010 & $(-3.22) * *$ \\
\hline STDRET & 0.0127 & $(0.65)$ & 0.2789 & $(8.51) * * *$ & 0.2767 & $(8.43) * * *$ & 0.4803 & $(7.47)^{* * *}$ & 0.0891 & $(4.79) * * *$ & 0.4494 & $(7.41) * * *$ \\
\hline DISPERS & -0.0006 & $(-1.10)$ & 0.0039 & $(4.31)^{* * *}$ & 0.0039 & $(4.30)^{* * *}$ & 0.0069 & $(3.86)^{* * *}$ & 0.0002 & $(0.34)$ & 0.0042 & $(2.47)^{* *}$ \\
\hline BETA & 0.0053 & $(4.66) * * *$ & 0.0211 & $(11.08)^{* * *}$ & 0.0211 & $(11.05)^{* * *}$ & 0.0262 & $(7.00)^{* * *}$ & 0.0099 & $(9.16)^{* * *}$ & 0.0185 & $(5.24) * * *$ \\
\hline MOM & -0.0213 & $(-14.46)^{* * *}$ & -0.0473 & $(-19.13)^{* * *}$ & -0.0474 & $(-19.12) * * *$ & -0.0442 & $(-9.11)^{* * *}$ & -0.0258 & $(-18.34)^{* * *}$ & -0.0125 & $(-2.74) * *$ \\
\hline SIZE & 0.0006 & $(1.33)$ & -0.0015 & $(-1.77)^{*}$ & -0.0015 & $(-1.86)^{*}$ & -0.0026 & $(-1.65)^{*}$ & 0.0010 & $(2.26)^{* *}$ & 0.0001 & $(0.06)$ \\
\hline$M B$ & -0.0004 & $(-3.09) * * *$ & -0.0007 & $(-3.44) * * *$ & -0.0007 & $(-3.45)^{* * *}$ & -0.0003 & $(-0.63)$ & -0.0003 & $(-2.51)^{* *}$ & 0.0015 & $(3.99) * * *$ \\
\hline \# of obs. & \multicolumn{2}{|c|}{2,727} & \multicolumn{2}{|c|}{2,727} & \multicolumn{2}{|c|}{2.727} & \multicolumn{2}{|c|}{2,727} & \multicolumn{2}{|c|}{2,727} & \multicolumn{2}{|c|}{2,727} \\
\hline Adjusted $R^{2}$ & \multicolumn{2}{|c|}{0.1363} & \multicolumn{2}{|c|}{0.2427} & \multicolumn{2}{|c|}{0.2421} & \multicolumn{2}{|c|}{0.1165} & \multicolumn{2}{|c|}{0.2005} & \multicolumn{2}{|c|}{0.0770} \\
\hline
\end{tabular}

$S T O C K=$ the ratio of total STOCK compensation for outside directors over total compensation for outside directors in a firm during the fiscal year; $O P T I O N=$ the ratio of total OPTION compensation for outside directors over total compensation for outside directors in a firm during the fiscal year; $C E O \_C O M P=$ ratio of total equity-based compensation for CEO over total compensation for CEO; $C E O / C H A I R=1$ if the CEO also holds chairman of the board, and 0 otherwise; OUTSIDE = total number of independent outside directors over total number of directors; $P R O B L E M=1$ if there is a director attendance problem (for each director, attendance rate should be above 75\%), and 0 otherwise; BOARDSIZE = total number of directors in a board; TOPOWN = the percentage of total share held by top five executives to total outstanding shares; STDRET = standard deviation of daily stock returns for the previous 24 months; DISPERS = the standard deviation of all forecasts made by analysts divided by median analysts' forecasts; BETA = estimates from Capital Market Asset Pricing Model; $M O M=$ stock return during the previous 12 months; SIZE $=$ log of market value of equity at the beginning of year; $M B=$ market-to-book value of equity ratio; (Asymptotic) $t$-statistics are in parentheses. ***, **, and * denote significance of parameter estimates at the $0.01,0.05$, and 0.10 levels, respectively. 


\section{SUMMARY AND CONCLUSION}

This paper investigates the relationship between the equity-based compensation for outside directors and cost of equity capital. We find that the proportion of equity-based compensation for outside directors is negatively associated with the cost of equity capital. These results hold after controlling for general corporate governance measures and other control variables that possibly affect the cost of equity capital. The results are also robust to additional tests using the amount of the equity-based compensation instead of the proportion, and separating equitybased compensation for outside directors into stock and options.

Overall, our findings are consistent in showing that the board of directors is interested in reducing the information asymmetry between managers and shareholders. By doing so, the cost of equity capital will be mitigated by lowering agency risks. This paper also can provide supplementary evidence that the equity-based compensation is one possible tool to improve the corporate governance structure.

\section{AUTHOR INFORMATION}

Induck Hwang is a candidate for the $\mathrm{PhD}$ in Accounting, College of Business, KAIST, Hoegiro 85, DongdaemoonGu, Seoul 130-722, Korea. Email: hydeme@business.kaist.ac.kr

Hyungtae Kim is an assistant professor in Department of Accounting, College of Business, Arkansas State University, Jonesboro, AR, 72467. Email: hkim@astate.edu

Sangshin Pae is an assistant professor in Department of Accounting, College of Business, Arkansas State University, Jonesboro, AR, 72467. Email: spae@astate.edu (Corresponding author)

\section{REFERENCES}

1. Aboody, D., \& Kasznik, R. (2000). CEO stock option awards and the timing of corporate voluntary disclosures. Journal of Accounting and Economics, 29, 73-100.

2. Adams, B., \& Ferreira, D. (2008). Do directors perform for pay? Journal of Accounting and Economics, 46, 154-171.

3. Ajinkya, B., Bhojraj, S., \& Sengupta, P. (2005). The association between outside directors, institutional investors and the properties of management earnings forecasts. Journal of Accounting Research, 43, 343376.

4. Ashbaugh, H., Collins, D., Kinney, W., \& Lafond, R. (2009a). The effect of SOX internal control deficiencies on firm risk and cost of equity. Journal of Accounting Research, 47, 1-43.

5. Ashbaugh, H., Collins, D., \& Lafond, R. (2009b). Corporate governance, risk and cost of equity. Working paper.

6. Attig, N., Guedhami, O., \& Mishra, D. (2008). Multiple large shareholders, control contests, and implied cost of equity. Journal of Corporate Finance, 14, 721-737.

7. Bhojraj, S., \& Sengupta, P. (2003). Effect of corporate governance on bond ratings and yields: The role of institutional investors and outside directors. The Journal of Business, 76, 455-475.

8. Botosan, C. (1997). Disclosure level and cost of equity capital. The Accounting Review, 72, 323-349.

9. Botosan, C., \& Plumlee, M. (2002). A re-examination of disclosure level and the expected cost of equity capital. Journal of Accounting Research, 40, 21-40.

10. Brick, I., Palmon, O., \& Wald, J. (2006). CEO compensation, director compensation, and firm performance: Evidence of Cronyism? Journal of Corporate Finance, 12, 403-423.

11. Bryan, S., Hwang, L., Klein, A., \& Lilien, S. Compensation of outside directors: An empirical analysis of economic determinants. Working paper. New York University, 2000.

12. Carcello, J., Hollingsworth, C., Klein, A., \& Neal, T. (2006). Audit committee financial expertise, competing corporate governance mechanisms, and earnings management. Working paper.

13. Claus, J., \& Thomas, J. (2001). Equity premia as low as three percent? Evidence from analysts' earnings forecasts for domestic and international stock markets. Journal of Finance, 15, 1629-1666. 
14. Chen, K., Chen, Z., \& Wei, K. (2009). Legal protection of investors, corporate governance, and the cost of equity capital. Journal of Corporate Finance, 15, 273-289.

15. Cordeiro, J., Veliyath, R., \& Neubaum, D. (2005). Incentives for monitors: Directors stock-based compensation and firm performance. Journal of Applied Business Research, 21, 81-90.

16. Dechow, P., Sloan, R., \& Sweeney, A. (1996). Causes and consequences of earnings manipulation: An analysis of firms subject to enforcement actions by the SEC. Contemporary Accounting Research, 13, 1-36.

17. Deutsch, Y. (2007). The influence of outside directors' stock-option compensation on firms' R\&D. Corporate Governance, 15, 816-827.

18. Easton, P. (2004). PE ratios, PEG ratios, and estimating the implied expected rate of return on equity capital. The Accounting Review, 79, 73-95.

19. Easton, P., \& Monahan, S. (2005). An evaluation of accounting-based measures of expected returns. The Accounting Review, 79, 73-95.

20. Fich, E., \& Shivdasani, A. (2005). The impact of stock-option compensation for outside directors on firm value. Journal of Business, 78, 2229-2254.

21. Francis, J., LaFond, R., Olsson, P., \& Schipper, K. (2004). Cost of equity and earnings attributes. The Accounting Review, 79, 967-1010.

22. Gebhardt, W., Lee, C., \& Swaminathan, B. (2001). Toward an implied cost of capital. Journal of Accounting Research, 39, 135-176.

23. Hail, L., \& Leuz, C. (2006). International differences in the cost of equity capital: Do legal institutions and securities regulation matter? Journal of Accounting Research, 44, 485-531.

24. Hope, O., Kang, T., Thomas, W., \& Yoo, K. (2008). Impact of excess auditor remuneration on cost of equity capital around the world. Working paper.

25. Jensen, M., \& Meckling, W. (1976). Theory of the firm: Managerial behavior, agency costs and ownership structure. Journal of Financial Economics, 33, 375-400.

26. Karamanou, I., \& Vafeas, N. (2005). The association between corporate boards, audit committees, and management earnings forecasts: An empirical analysis. Journal of Accounting Research, 43, 453-486.

27. Klein, A. (2002). Audit committee, board of director characteristics and earnings management. Journal of Accounting and Economics, 33, 375-400.

28. Linn, S., \& Park, D. (2005). Outside director compensation policy and the investment opportunity set. Journal of Corporate Finance, 11, 680-715.

29. Nagar, V., Nanda, D., \& Wysocki, P. (2003). Discretionary disclosure and stock-based incentives. Journal of Accounting and Economics, 34, 283-309.

30. Ohlson, J., \& Juettner-Nauroth, B. (2005). Expected EPS and EPS growth as determinants of value. Review of Accounting Studies, 10, 249-365.

31. Perry, T. (2000). Incentive compensation for outside directors and CEO turnover. Working paper.

32. Ryan, H., \& Wiggins, R. (2004). Who is in whose pocket? Director compensation, board independence and barriers to effective monitoring. Journal of Financial Economics, 73, 497-524.

33. Vafeas, N. (1999). Board meeting frequency and firm performance. Journal of Financial Economics, 53, 113-142.

34. Warfield, T., Wild, J., \& Wild, K. (1995). Managerial ownership, accounting choices, and informativeness of earnings. Journal of Accounting and Economics, 20, 61-92.

35. Yermack, D. (1996). Higher market valuation companies with a small board of directors. Journal of Financial Economics, 40, 185-211.

36. Yermack, D. (2004). Remuneration, retention, and reputation incentives for outside directors. Journal of Finance, 59, 2281-2308. 